\title{
PREFACE, BCREC VOL. 11 NO. 3 YEAR 2016
}

\author{
I. Istadi (Editor-in-Chief) \\ Department of Chemical Engineering, Diponegoro University,E-mail: istadi@che.undip.ac.id
}

DOI: 10.9767/bcrec.11.3.726.v-vii

Bulletin of Chemical Reaction Engineering \& Catalysis (e-ISSN: 1978-2993) is an international journal published by Department of Chemical Engineering, Diponegoro University, jointly with Masyarakat Katalis Indonesia - Indonesian Catalyst Society (MKICS). In Scopus coverage years 20112015, this journal was ranked 38 $8^{\text {th }}$ (Q4 level) in Scimago for Catalysis category and ranked 29 ${ }^{\text {th }}$ (Q4 level) in Scimago for Process and Chemistry Technology category. In addition, this journal has also a good impact factor in Scimago Journal Ranking / Journal Metrics (SJR = 0.192; SNIP = 0.477; IPP = 0.533) for coverage years 2011-2015. Since 2015, this journal has also been listed in Master Journal List of Thomson Reuters-Web of Science Core Collection Database (Emerging Source Citation Index), and under evaluation to be indexed in Science Citation Index Expanded (to be included in Journal Citation Report (JCR)). Thank you for the great contribution to all respectful Authors, Peerreviewers, and Editors.

This issue (Bull. Chem. React. Catal. Eng., Volume 11, Issue 3, Year 2016 (December) has published 17 articles (16 original research articles and one review article). This issue was authored and coauthored by 57 authors from 9 countries (Indonesia, Russia, Malaysia, Iran, China, Algeria, India, Brazil, and Kazakhstan). This issue has available online since 12 October 2016 for the reqular issue of December 2016.

In this issue, there are two articles focused on enzymatic catalysis reaction, i.e. surface modification of macroporous matrix for immobilization of lipase for fructose oleic ester synthesis studied by Hilmanto et al. and enzymatic phorbol esters degradation using the germinated Jatropha curcas seed lipase as biocatalyst: optimization of process conditions by response surface methodology studied by Wardhani et al. Hilmanto et al. indicated that PPA was successfully attached on matrix. For HHM, an increase in the peak area of $\mathrm{NH}_{2}$ bond indicated that PEI was also successfully attached on the matrix. The optimum conditions of lipase adsorption were obtained at buffer $\mathrm{pH} 7$ containing $0.5 \mathrm{M}$ $\mathrm{NaCl}$ (9.27 mg protein/g matrix) and without $\mathrm{NaCl}(9.23 \mathrm{mg}$ protein/g matrix) for the yields of HM and HHM of $75.96 \%$ and $85.29 \%$, respectively. Wardhani et al. reported that a Response Surface Methodology (RSM) using three-factors-three-levels Box-Behnken design was used and showed that the optimum conditions of PE degradation (98.96\%) were $29.33 \mathrm{~h}, 51.11: 6(\mathrm{~mL} / \mathrm{g})$, and $30.10: 5(\mathrm{U} / \mathrm{g}$ cake) for the reaction time, the ratio of buffer volume to DJSC, and the ratio of enzyme to DJSC, respectively.

Another article focused on photocatalyst are $\mathrm{ZnO} / \mathrm{Mg}$-Al layered double hydroxides as a photocatalytic bleaching of methylene orange by using a black box modeling by artificial neural network studied by Hosseini \& Akbari, and reduction of peroxide value and free fatty acid value of used frying oil using $\mathrm{TiO}_{2}$ thin film photocatalyst investigated by Kaltsum et al. They found that the optimized conditions were obtained at $600{ }^{\circ} \mathrm{C}, 120 \mathrm{~min}, 0.05 \mathrm{~g}$ and $20 \mathrm{ppm}$ for the calcination temperature, irradiation time, catalyst amount and dye pollutant concentration, respectively. The last study concluded that $\mathrm{TiO}_{2}$ thin films reduced FFA and PV of used frying oil up to $67.10 \%$ and $79.15 \%$, respectively. The photocatalytic activity of annealed $\mathrm{TiO}_{2}$ thin film was higher than as-deposited $\mathrm{TiO}_{2}$ thin film. The results indicated that $\mathrm{TiO}_{2}$ thin film photocatalyst potential as the new alternative method to purify used frying oil. 
There are three articles which focused on the natural raw materials as a catalyst. Both articles are methyl methacrylate and alpha-methyl styrene: new strategy for synthesis of bloc copolymers for use in potential biomedical applications generated by an ecologic catalyst called Maghnite (Algerian MMT) studied by Ayat et al., other articles focused on this natural material utilization is selective synthesis, characterization and kinetics studies of poly(a-methyl styrene) induced by Maghnite-Na+ clay (Algerian MMT) by Ayat et al., and physicochemical and photocatalytic properties of Fe-pillared bentonite at various Fe content investigated by Fatimah \& Nurkholifah. The former researchers concluded that the yield of copolymerization depends on the amount of $\mathrm{Na}^{+}$-MMT used and the reaction time. The kinetic studies indicated that the polymerization rate is first order with respect to monomer concentration. A cationic mechanism for the reaction studies showed that monomer was inserted into the growing chains. The last researchers found that the pillared bentonite physicochemical character is affected by the iron content in a precursor solution. By the Fe content variation, it was found that the Fe content in Fe/Bents is not linearly correlated with the specific surface area and the increased in d001 in which both the maximum specific surface are and do01 reach maximum at the Fe content of $20 \mathrm{mmol} / \mathrm{g}$. Due to the kinetics of photocatalytic activity in phenol removal, it is concluded that in photo-Fenton-like processes.

Other studies were focused on developing nickel-based catalysts, they are fasification of nickelpreloaded oil palm biomass with air studied by Syed-Hassan \& Nor-Azemi, as well as oligomerization of $\mathrm{C}_{2}-\mathrm{C}_{4}$ hydrocarbons in the presence of ruthenium-nickel supported catalysts investigated by Toktassyn et al. They found that nickel species was found to disperse very well on the biomass at a nano-scale dispersion which in turn enhanced syngas production and reduced tar content in the producer gas during the air gasification of biomass. It is believed that nickel particles attached on the biomass and its char promote the catalytic cracking of tar on their surface and supply free radicals to the gas phase to enhance the radical-driven gas-phase reactions for the reforming of high molecular weight hydrocarbons. The last study concluded that the ruthenium-nickel supported bimetallic pillared montmorillonite showed good selectivity to isooctane $(60.8 \%)$ at a conversion of $87.0 \%$.

Some researchers studied on cracking or pyrolysis catalysts, they are silica-supported $\mathrm{Co}_{3} \mathrm{O}_{4}$ nanoparticles as a recyclable catalyst for rapid degradation of azodye studied by Baghban et al. and kinetic study of the catalytic pyrolysis of oil-containing waste investigated by Chalov et al. They stated that treating methyl orange (MO) with ammonium persulfate in the presence of $\mathrm{Co}_{3} \mathrm{O}_{4} / \mathrm{SiO}_{2}$ led to complete degradation of MO under the optimized conditions and exhibited recyclability at least over 10 consecutive runs. Another catalyst of $\mathrm{CoCl}_{2}$ with the catalyst loading $5 \%$ (wt.) of the substrate weight, it was found that the activation energy of the catalytic pyrolysis of oil-containing waste decreased by $20-30 \mathrm{~kJ} / \mathrm{mol}$ in comparison to non-catalytic process.

The other research focuses on this issue are ultrasonically promoted synthesis of ethyl 2-(naphthalen2-yloxy)acetate in solid-liquid heterogeneous phase transfer catalysis condition studied by Abimannan \& Rajendran; sustainable catalytic process for synthesis of triethyl citrate plasticizer over phosphonated USY zeolite investigated by Nandiwale \& Bokade; liquid-phase hydrogenation of phenol to cyclohexanone over supported palladium catalysts studied by Fan et al., preparation of $\mathrm{FeO}(\mathrm{OH})$ modified with polyethylene glycol and its catalytic activity for the reduction of nitrobenzene with hydrazine hydrate investigated by Cai et al., and microscopic phase structure of Mo-based catalyst and its catalytic activity for soot oxidation studied by Mei et al. They found various metal oxides and zeolite based catalyst for the various useful processes.

A review article about advanced chemical reactor technologies for biodiesel production from vegetable oils was studied by Buchori et al. In this study, they stated that microwave and ultrasound assisted transesterification significantly can reduce reaction time as well as improve product yields. Another potential process is a plasma technology which is promising for biodiesel synthesis from vegetable oils due to very short reaction time, no soap formation and no glycerol as a by-product. This paper reviews 
briefly the technologies on transesterification reaction for biodiesel production using homogeneous, heterogeneous, and enzyme catalysts, as well as advanced methods (supercritical, microwave, ultrasonic, and plasma technology). Advantages and disadvantages of each method were described comprehensively.

Currently, Bulletin of Chemical Reaction Engineering \& Catalysis journal is an open access international journal under licensed a Creative Commons Attribution-ShareAlike 4.0 International License (CC-by-SA). Therefore, readers can read and download any full-text articles for free of charge. Official website address of BCREC journal is: http://bcrec.undip.ac.id. The Editor would like to appreciate and to call for papers all researchers, academicians, industrial practitioners focused on chemical reaction engineering and catalysis to contribute to this international journal.

\section{Semarang, Indonesia, October 2016}

\section{Istadi (Editor-in-Chief)}

Department of Chemical Engineering, Diponegoro University

E-mail: istadi@che.undip.ac.id 